\title{
"...A 40-year-old black man made the point to me": Everyday Knowledge and the Performance of Leadership in Contemporary British Politics
}

In the first of the leaders' debates held during the 2010 General Election campaign, David Cameron, addressing the issue of immigration policy, recounted the following story:

I was in Plymouth recently, and a 40-year-old black man made the point to me. He said, "I came here when I was six, I've served in the Royal Navy for 30 years. I'm incredibly proud of my country. But I'm so ashamed that we've had this out-of-control system with people abusing it so badly" (quoted in Burkeman, 2010).

This remark caused some amusement. The references to location, age and ethnicity feel forced - and as a rule the Royal Navy does not recruit people at the age of ten. Newspapers subsequently reported that the man in question was Neal Forde; fifty-one years old, he served in the Navy for six years and was of the view that 'Britain needs immigrants' (Guardian, 2010).

Mr. Forde was not the only person to have a strange walk-on part in the United Kingdom's first televised election debate. David Cameron had also recently met a crime victim from Crosby, a drug addict from Witney and a man suffering from cancer of the kidney. Liberal Democrat leader Nick Clegg had been talking to a wardnurse in a short-staffed hospital and a burglary victim from London. Gordon Brown had met a trainee chef and received a letter from a recovered cancer patient. ${ }^{1}$ Of all the rhetorical strategies employed in the first election debate, these anecdotes about "real people" were one of the most common. 
In this article we show that, in Britain, the use of these kinds of anecdote in political speech has recently become more extensive. In examining and assessing this development, we make use of Rhetorical Political Analysis which focuses on the varied kinds of proof or justification found in political argument (see Finlayson, 2004, 2007; Finlayson and Martin, 2008). In the leadership debates, where they could have justified claims by reference to factual evidence, expert testimony, or the "core values" of their own party, the leaders instead chose to tell anecdotes about, and quote from, the experiences of real people. The increasing use of such proofs is, we argue, part of a populist shift in the "rhetorical culture" of contemporary British politics.

The article begins with a brief discussion of approaches to the study of political language and communication and an outline of what Rhetorical Political Analysis (RPA) can bring to the field. We then discuss how rhetoricians understand the use of such anecdotes, before exploring their use in one of the few genres of British political speech to provide a sufficiently long run of examples to make the identification of trends possible: the party leader's speech to conference. Our research indicates a recent rise in the use of such anecdotes and we explore some examples in detail. In a fourth section, we explore the "rhetorical culture" indicated by the use of such anecdotes, arguing that it is congruent with broader developments in "epistemological culture" and that its use in politics is one aspect of a more general "populist" ideology. The article is thus a contribution to theoretical and empirical research into the historical and cultural conditions of the production and circulation of ideas and arguments in politics. In particular, it develops and tests the method of Rhetorical Political Analysis, linking this to the study of political communication and opening up for further consideration the study of "rhetorical cultures". 


\section{Analysing Political Speech}

There is not yet a single, systematic, overarching research programme focused on political speech in Britain (but see Toye, 2011; Finlayson and Martin, 2008). However, political speeches are often an object of analysis and scholars are becoming more methodologically self-conscious about how best to use them in the study of political ideas, ideologies and actions. There are quantitative analyses (e.g. Kenny, 2010; Meisel, 2001) and theory-driven studies of political discourse (Laclau, 1990, 2007; Glynos and Howarth, 2007), as well as research into the interaction between political ideas, traditions and narratives (Bevir and Rhodes, 2003, 2007, 2008). Moreover, different approaches have developed within the study of leadership, such as Edelman's $(1985,1988)$ examination of the use of language in the "construction" of reality by both leaders and led. In the UK, meanwhile, cultural theorists have explored the symbolic and ideological meaning of political leaders' image and discourse (e.g. Hall and Jacques, 1989; also Gaffney, 2001), which is also a concern for studies of political marketing (Scammel, 1996; Savigny, 2005, Wring, 2005). Alongside this, there is a growing body of historical research into British political speech (Meisel, 2001, Lawrence, 1998, 2006, 2009; Matthew, 1987), and within linguistics there have been studies of the language of British politics (e.g. Beard, 1999; Chilton, 2003), its power (Fairclough, 2001) and defining metaphors (CharterisBlack, 2005). All of these approaches are valuable. However, there remains a challenge for political analysis: to integrate findings into the broader research programmes of political theory and political science, and in particular those concerned with the formation, propagation, development and change of ideas in politics. For this, we favour the approach of Rhetorical Political Analysis (RPA). 
RPA focuses on the arguments found in political speech, and especially the proofs actors bring forward in justifying claims and giving reasons for others to share them (see Finlayson, 2004, 2007, 2012; Finlayson and Martin, 2008; Glynos et al, 2009). In political dispute what is at issue may be not only the content, logic and value of specific proposals, but also the criteria with which these are assessed, evaluated and proven. Rhetorical proofs include those that rest on the character of a speaker (or on the citation of an 'authority'), appeals to the emotions and quasi-logical attempts to reason from contested or uncertain premises. Particular combinations of appeal, allied to rhetorical figures and narrative organisation, invite audiences to see things in particular ways and to make particular deductions or inferences. In examining these combinations (their history, development, change and use), RPA is studying a vital aspect of political practice and the conditions within which it takes place. That is because how something is argued for is not wholly separate from what is argued; the historical and cultural frameworks of argument (its form and expectations) condition what is arguable (see Nelson et al, 1991; Fish, 1989). Political speech and argument emerge from (and feed into) a "rhetorical culture"- the shared, changing, sometimes varied and often contested expectations of how claims about the political world may be appropriately and legitimately formulated and justified. Rhetorical culture specifies (in both technical and normative ways) how speech should work, giving rise to what Hirschmann has described as 'imperatives of argument' (1991: x). In aiding identification of such imperatives and facilitating analysis of their form and 'logic' (Glynos and Howarth, 2007), RPA connects studies of political communication and leadership style with the theoretical analysis of political ideas and ideologies (see Finlayson, 2012). 


\section{Anecdote in the Rhetorical Tradition}

Rhetorical analyses may examine single instances of rhetoric (speeches, essays, debates), the rhetorical style of particular individuals (or movements), or the rhetoric shaping debate about a particular issue (see Benson, 1993; Rowland, 1999). We may also examine specific rhetorical phenomena, and in the present case we are interested in the use of the kinds of anecdotes which appeared, in abundance, in the leaders' debates of 2010. These have much in common with the use in rhetoric of what Aristotle called 'witnesses': anyone (or anything) we bring into our speech to support our claims; anyone whose thoughts might bring insight and whom we think our audience will take seriously. They may be 'ancient' - such as 'the poets and all those other famous men whose judgements are well known' - or 'recent', namely 'notables who have given some judgement' (1375b). The most common use of such 'witnesses' in contemporary rhetoric is, of course, as quotation, one form of the 'argument from authority'. This proof relies on the stature with which the source quoted is held (and thus on collective assumptions about what counts as a valid knowledge claim, and who can make one). Closely related to the quotation are all sorts of sayings proverbs, maxims, apothegms, sententia - which sum up and express a thought, and the force of which rests on the stature of the one who said them or on their sheer venerability (see also Bentham, 1952).

A closely related rhetorical construction is called, in classical rhetoric, chreia: the telling of a story about a well-known person so as to edify and instruct. Here, quotation takes its place in a larger story. This is closely related to the parable, the story with a moral message that often works by means of an extended metaphor 
(Lanham 1991, p. 107). But the parable, like the fable, is wholly invented. In contrast, the use of a story in political rhetoric, although it may remain thoroughly metaphorical, has force because of its presumed reality: the source confers authority, and the actuality of the events enables a conclusion about reality to be drawn. Quotation and chreia thus shade into 'testimony' - the longer presentation of the statements of another - the function of which, as Serjeantson observes in relation to Renaissance uses of testimony, is not only to introduce witnesses who help prove a case but also to provide 'testimonial to the author himself, demonstrating his participation in a shared intellectual culture. The authority of the testimony was also conferred on the author who cited it' (2007, p. 192).

The anecdote combines quotation and testimony into a story that is also a "case" - an instance of reality presented as a kind of rule or a norm. That is to say, the anecdote is also an invitation to induction. In their classic The New Rhetoric, Perelman and Olbrechts-Tyteca identify three ways in which such cases are employed. The first is as a generalization, an attempt to indicate the presence of a rule; the second is as an illustration - the demonstration and reinforcement of a rule that is already established (1969, pp. 350-362). Cameron, in his "Plymouth Story", sought to draw on the "authority" of Neal Forde, the authentic testimony of an immigrant. In the telling Forde became "the sort of person" who worries about immigration (a substitute for a rival rule that everyone worried about immigration is a white bigot). Cameron's story may also be seen as a third use of examples: the "model" presented for imitation. Forde was also an exemplar of immigration, contrasting with those "abusing the system". Exemplum was a central feature of Renaissance literature which often depicted models of excellence (Hampton 1990, p. xi). As attempts to educate 
judgement and identify moral behaviours, the presentation of exemplars is inherently ideological, and changes in types of exemplar symptomatic of ideological and political conflicts that demand new representations of ideal conduct (Hampton 1990, pp. 17, 5).

Anecdotes can exemplify situations as well as individuals. The influential American rhetorical theorist Kenneth Burke coined the term 'representative anecdote' for a story that works as a synecdoche (1969a, p. 326). That is, one which represents a part for the whole (as when we refer to a car as our "wheels" or to a company of cavalrymen as "twenty horses"). Burke's point was that the anecdote is a "part" of reality presented in such a way that it stands for "the whole" of it (or of that aspect with which a writer or speaker is concerned). The story invokes an idea of what things are "really like" and from this certain things may be shown (or implied) to follow.

Burke's concept of "identification: is also relevant here - the feeling that the interests of two individuals are in harmony which can in part be achieved through the use of a style which others share $(1969 \mathrm{~b}$, pp. $21,62,46)$. In anecdotes the style of others is directly incorporated into a discourse. Through the trope of prosopopoeia - which literally means 'to make a face', to speak as, or in the words of, another - we are invited to identify with the person whose story is told as well as with the one telling it, and in ways that may evoke feelings absent from more general descriptions (Charteris-Black 2005, p. 12).

In the anecdote we find a dense convergence of rhetorical forces and processes. It is sometimes a proof from an authority, and sometimes a type of evidence presented in 
the form of an example from which generalisations may be induced. It is an illustration of reality; a model for imitation; an affirmation of ethos; a representation of an ideal; a spur to emotion; a claim about the structure of reality. Where they involve the use of everyday language and descriptions of everyday experiences, anecdotes may also engender identification not merely between persons, but between ways of thinking.

Importantly, anecdotes are necessarily culturally embedded, drawing from and invoking (what are presumed to be) generally accepted norms and reference points. A change in their form or content (including the kinds of "authorities" or exemplars they invoke) is likely to be related to a change in such norms, a change in what rhetoricians believe about others' norms, or to an attempt to bring about such a change. In this respect, changes in rhetorical culture are part of changes to social, ideological and political practice.

\section{Anecdotes in British Political Speech}

The extensive use of anecdotes in the televised leaders' election debate is indicative of an aspect of rhetorical culture. An examination of party leaders' speeches to their annual conference or convention from 1895 to the present day (restriction to this genre enabling comparison across time as opposed to synchronic comparison between genres) revealed how recent is the prominent use, as a rhetorical proof, of "stories" about "everyday" experience. The table below shows the number of anecdotes found in these speeches, arranged by party, since 1990. 


\begin{tabular}{|c|c|c|c|c|}
\hline Year & Con & Lab & Lib & Total \\
\hline 1990 & 0 & 0 & 0 & 0 \\
\hline 1991 & 1 & 0 & 0 & 1 \\
\hline 1992 & 1 & 0 & 0 & 1 \\
\hline 1993 & 2 & 0 & 2 & 4 \\
\hline 1994 & 0 & 0 & 1 & 1 \\
\hline 1995 & 2 & 2 & 0 & 4 \\
\hline 1996 & 1 & 8 & 3 & 12 \\
\hline 1997 & 0 & 5 & 0 & 5 \\
\hline 1998 & 1 & 3 & 0 & 4 \\
\hline 1999 & 5 & 2 & 0 & 7 \\
\hline 2000 & 6 & 1 & 1 & 8 \\
\hline 2001 & 2 & 2 & 2 & 6 \\
\hline 2002 & 0 & 5 & 0 & 5 \\
\hline 2003 & 1 & 10 & 0 & 11 \\
\hline 2004 & 4 & 6 & 8 & 18 \\
\hline 2005 & 3 & 1 & 1 & 5 \\
\hline 2006 & 7 & 4 & 2 & 13 \\
\hline 2007 & 12 & 4 & 4 & 20 \\
\hline 2008 & 5 & 9 & 5 & 19 \\
\hline 2009 & 5 & 7 & 3 & 15 \\
\hline 2010 & 8 & 4 & 1 & 13 \\
\hline
\end{tabular}

Prior to 1990 anecdotes occur irregularly, but there is extensive use of quotation from various sources (e.g. newspapers, literature and other politicians). This has declined as the anecdote has risen. For example, in 1980 the leaders' speeches made notable use of quotations ten times, and in 1985 nine times. In the sample years 2000, 2005 and 2010, there were no uses of significant quotation other than those which occurred in the context of anecdotes about ordinary people. Furthermore, since the 1990s the form taken by these anecdotes stabilises into two main types: stories about the leaders themselves, and stories about a person with whom they have had contact.

To be sure, Margaret Thatcher famously referred to her "ordinary" background as the daughter of a grocer. However, she did so simply by stating the fact and not in the form of an anecdote. ${ }^{2}$ Nor were her experiences often employed as illustrative proofs of a more general political point (her own ethos excepted). For instance, in her early 
speeches to the party conference as leader and Prime Minister, Thatcher made passing evaluative reference to personal experiences such as visiting Communist countries (Thatcher, 1975) or meeting people in Northern Ireland (Thatcher, 1978). In 1979 (in an example we return to below), she read from a letter sent by 'a small businessman in the West Midlands' (Thatcher, 1979). This is one of the earliest examples, in the conference speech, of the anecdotal testimony of an "ordinary" person being employed as an authority and as a proof of a more general political point.

The evidence from party leaders' speeches to conference is that there has been a marked shift in the kind of "witnesses" employed in this genre of political rhetoric in what is considered to be an authority and an exemplar. The change appears first, sporadically, in the speeches of the Conservative leader, is later picked up by the Labour Party (with some gusto), and rapidly spreads across parties and persists through different leaders. This spread suggests that the development is not simply a quirk of individuals, but a more general change in rhetorical culture. To work out what is going on here, we need to look more closely at some examples.

Many of the anecdotes concern leaders' family background or childhood experiences (e.g. Blair, 1996; Brown, 2007, 2008; Hague, 2000; Howard, 2004; Major, 1995; Miliband, 2010.) Here is Menzies Campbell addressing the 2006 Liberal Democrat party conference:

I was born in a tenement in Glasgow. My parents worked hard to provide me with the opportunities that they never had. My father wanted to be a doctor, but couldn't afford to go to university. So they saw to it that I got the chances they did not (2006). 
Here, Campbell first invites sympathy and identification with himself (and with his parents) as ordinary hard-working people. He went on to describe how he, in common with most people in Britain, had benefited from public services: 'You know, my education was paid by for by the state, the sports facilities where I trained as an athlete were paid for by the state - and the health care that I have received was paid for by the state' (2006). Having opportunities that his family would otherwise have been unable to afford, Campbell said, had taught him the 'true value of public services', how they 'provide the essentials of a decent society, and ... create opportunity' (2006). Campbell's representation of his personal experience is part of a proof of the importance and effectiveness of public services. His own experience presented as exemplary - stands for the whole, while inviting emotive identification such that the audience may 'believe that their values are transposed into the aspirations and commitments he articulates' (Faucher-King 2005, p. 81).

The same thing done differently can be found in David Cameron's 2007 speech. Given his wealthy background, Cameron could not tell the same sort of story as Campbell, and sought to make a virtue of his honesty about this: 'I can't give you some hard luck story. I'm the son of a magistrate and a stockbroker, but the great privilege of my upbringing wasn't the wealth, it was the warmth, it was the family'. Such candour contributes to an ethos of honesty while Cameron also gets to make a Conservative point: that wealth inequality does not matter, whereas strong family does. He used personal experience to prove his qualifications to make education policy: 'I went to a fantastic school... I had a great education and I know what a great education means. And knowing what a great education means, means there is a better 
chance of getting it for all of our children'. He also talked about the influence of his mother: 'she believed in public service, and so do I' (2007).

These contributions to the formation of the public 'character' of Cameron came at the end of a speech that had started with Cameron recalling the conference nearly twenty years previously, the year the Berlin Wall came down. He then reminisced about his travels through Eastern Europe in the Communist era, marking the difference between then and now. Across the rest of the speech he told a brief story about almost every area of policy: experience teaching in a school and instances of behavioral problems encountered by teachers he met; a constituent with cancer finding his pension has gone bust; an ex-convict going straight but unable to marry because of the cost to his benefits; his own experiences of the NHS treating his son; a visit with soldiers in Camp Bastion in Afghanistan; walking the beat with a police officer in mid-Wales. Each of these functioned as a 'representative anecdote' from which could be induced the nature of a whole system. And by placing himself in them, Cameron sought to establish identification, before closing the speech with reference to his own background and the tradition of public service from which he came and sought to embody.

In outlining his motivations for entering politics, Cameron was doing something very common (e.g. Blair, 1996; Brown, 2007, 2008; Cameron, 2007, 2008, 2009; Campbell, 2006; Howard, 2004, 2005; Kennedy, 2000; Major, 1996; Miliband, 2010). In a memorable performance William Hague - usually a gifted public speaker invited his listeners to: 
Come with me to the Rother Valley, to the heart of South Yorkshire... Come and meet the people I grew up with. Children of proud mothers who struggled with small budgets... who hoped for a better life for their sons and their daughters. Children of fathers who worked hard in mines and on farms and in steel works... who had no choice but to live from one week's pay packet to the next (2000).

He explained that many of his peers now had their own families and, while better off than their parents, nonetheless shared their forefathers' desire for security and aspiration for a better life. For Hague, these people, 'and millions like them, are the mainstream of our country. They are the people who motivate me'. All of this was a - rather transparent - attempt to engender identification and overturn Hague's image as a 'Hansard-reading teenage conformist and tweed-jacketed Young Conservative' (Nadler, quoted in Bale 2010, p. 77). But, importantly, it was joined with claims that people were being let down by politicians out of touch on crime, taxation and Europe. Hague appealed directly to this neglected majority: 'We will govern for hard-working families', he declared, 'We will govern for people of every community and background. We will govern for the mainstream that New Labour has ignored. We will govern for all the people' (2000). The story of the Rother valley was a 'representative anecdote', Hague's home town the part that stood for the whole of Britain, his friends the examples of the norm and his party the natural place of identification for the 'hard-working, hard pressed, decent law-abiding people of this country' (2000; see also Bale 2010, p. 111).

There are many examples of these sorts of story. They will be familiar not only from conference addresses, but also from party political broadcasts that concentrate on 
leadership character (e.g. Finlayson 2003, Ch.1; Scammell, 1996; 2007) and from personalised television interviews. RPA identifies such anecdotes not just as "brand development", but as attempts to claim legitimate authority through identification and to prove claims about policy by allying them with claims about reality. In this respect Colin Hay may be mistaken to suggest that today 'Assessments of party leaders' character traits, credibility and trustworthiness ... tend to replace those of policy substance' (2007, pp. 56-57). The establishment of character traits and experience is not a substitute for the justification of policy, but a way of doing so. And what is noticeable is the extent to which those traits primarily consist of ordinariness while appeals to expertise are supplanted by appeals to everyday experience. The significant change here is not a reduction of policy substance to the superficiality of image but, rather, a shift from one way of demonstrating and articulating policy knowledge to another: a development in rhetorical culture.

Here is another example. At Labour's first conference following the invasion of Iraq, Tony Blair sought to renew his authority with a wary party. He did so by connecting his choice in foreign policy with his general policies of 'modernisation', and then relating his personal experience as a party member. Reminiscing about the 1985 conference, when Neil Kinnock famously used his speech to launch an attack on the Militant tendency, Blair said:

I remember when our journey to Government began. Here in this hall in $1985 \ldots$... And of course today it seems absurd, doesn't it? Militant, Arthur [Scargill], all that nonsense. But I tell you. At the time, I remember up there, where the MPs used to be penned in, getting to my feet in the 
middle of his speech, the Hall split asunder, my heart pounding, wondering if this was the beginning or the end (2003).

Validating the present by marking its distance from the past Blair described the situation in colourful, amplified terms ('penned in', 'asunder', 'pounding'), the specific situation standing for the whole of that political period, concluding:

And what I learnt that day was not about the far left. It was about leadership. Get rid of the false choice: principles or no principles.

Replace it with the true choice. Forward or back. I can only go one way. I've not got a reverse gear.

Here, again, the justification of policy rests on an appeal to personal experience and feeling (Blair's own and that of his audience of party members). This appeal overlaps with the second sort of anecdote that litters recent conference speeches and which we have already observed in Cameron's 2007 speech (as well as in the leader's debate): communication with ordinary people.

Earlier in that 2003 speech Tony Blair had claimed that, in motivating himself for reform:

I think of the people I meet. Holly in Southampton. Teenage mum. Now through Sure Start with childcare. Given help to study so she can become a midwife so she can work in the NHS so another mother can benefit ... the NHS manager in Newcastle, 30 years working in the NHS, telling me only in the last three has he done anything other than managing decline or the Chief Police Officer telling me after a lifetime in the service, that it was only with the recent legislation on crime he felt Government understood. 
The provision of this kind of proof that a government's policies are working is a primary function of such anecdotes as they appear in the contemporary conference speech (e.g. Blair, 1996, 1998, 2000, 2002, 2004, 2006; Brown, 2007, 2008, 2009; Cameron, 2006, 2007, 2008, 2009, 2010; Campbell, 2007; Clegg, 2008, 2009, 2010; Duncan Smith, 2001; Hague, 2000; Kennedy, 2004; Major, 1995; Miliband, 2010). In that 2003 speech Blair also told the story of an elderly woman from the North West of England, who had cared for her sick husband despite her own ill-health. After her husband died, she finally agreed to have the heart operation she urgently needed, only to be placed on a year-long waiting list. 'Once she would have had no choice', Blair claimed, but 'Now she did. Because of our policies, she was offered the chance to travel to get her heart operation done much more quickly. She jumped at it'. Blair continued: "After the operation she said: "I'd go to the ends of the earth to get my health back. It saved me six months of anxiety. Really I feel it saved my life", (2003). In this story the success of policy is proven, and the virtue of choice amplified, by means of an appeal to the authority of an unnamed 'elderly woman' and the use of her 'testimony'. She is also an exemplar of self-sacrifice and decency, and her single case is made to stand for an entire policy, enabling Blair to conclude the implied logic thus: 'Choice for her is not a betrayal of our principles. It is our principles' (2003).

Where those in office employ stories to prove the success of policy, opposition leaders, naturally, do the opposite (e.g. Ashdown, 1996; Cameron, 2007, 2008, 2009; Hague, 1999, 2000; Howard, 2004, 2005). Cameron, in 2008, argued that New Labour's numerous bureaucratic reorganisations of the NHS constituted 'superficial, short-term tinkering' rather than a long-term programme of reform (2008). Proof - 
and pathos - came from a letter he had received from a constituent named John Woods, whose wife had died after contracting MRSA in hospital. After telling his audience that 'some of the incidents described are so dreadful, and so degrading, that I can't read you most of the letter' - the trope of praeteritio, emphasising something by ostentatiously not mentioning it - Cameron quoted Mr Woods' report that the treatment his wife had received 'was like something out of a 17th century asylum, not a 21st century $£ 90$ billion health service', and his painful recollection of his wife 'sitting on the edge of her bed in distress and saying "I never thought it would be like this"” (2008).

Cameron reported that he had forwarded the letter to the Health Secretary, and read out a series of extracts from the reply which formally outlined the procedure for making a complaint against the hospital. He summed up powerfully: 'A Healthcare Commission. A Health Service Ombudsman. A Patient Advice and Liaison Service. An Independent Complaints Advocacy Service. Four ways to make a complaint, but not one way for my constituent's wife to die with dignity' (2008).

Here, Mr Woods is a witness, someone whose testimony supports a critique of health policy and the claim that reform of the NHS is vital. His words amplify the emotions and stimulate disbelief and outrage. The analogy of $17^{\text {th }}$ century asylum undermines Labour claims to have "modernised" the service (and implies that the whole thing is insane). One is invited to identify sympathetically with Mr. Woods' situation and also to see it as representative, an instance of a "rule", a part standing for the whole of the errors in the health service and, more than that, the whole of a bureaucratic and impersonal state at odds with the simple demand for individual dignity. Conservative 
policies, Cameron explained, would restore choice to people such as Mr. Woods, making the NHS 'a service ... not a take it or leave it bureaucracy' (2008). Thus a policy conclusion was derived from a diagnosis of the problem presented in the form of prosopopoeia, through the voice and face of the otherwise unknown Mr. Woods, with the whole taking the form of a representative anecdote.

We have here reviewed in detail only a fraction of the anecdotes found in leaders' speeches to conference and have outlined only their main elements. But it is clear that although some are more directly concerned with the cultivation of an image of leadership, and others with recounting the experiences of "ordinary" people, the line between these two blurs. The anecdotes are presented as extracts from reality, inductive proofs for general claims about political necessity which rely, primarily, on reference to everyday feeling and experience.

\section{The Rhetoric of Anecdotes: Context and Meaning}

To explore fully this development in rhetorical culture would require us to look in depth at the multiple contexts from which it emerged: the developing genres of the conference speech; the history of the arguments over the issues they are used to address; the place within the culture more generally of the themes and images on which they draw. We would have to place the particular anecdotes fully within their 'rhetorical situation' (see Bitzer, 1999) and in relation to the history of the political ideas, words and concepts they employ or invoke (see Connolly, 1974; Freeden, 1998). We would also have to connect these findings with research into developments in leadership style and political communication (e.g. Gaffney, 1991; Blumler and 
Kavanagh, 1999; Coleman and Ross, 2010) and into the growth of segmented political campaigning, targeted polling and focus groups (see Smith and Hirst, 2001).

In the following discussion we touch on these matters but, due to space constraints, concentrate on exploring the ideological context and implications of the rise to prominence of proofs based on an appeal to the authority of the "ordinary". In the past, leaders regularly employed as proof quotations provided by newspapers, official reports, citations of historic figures from the party's intellectual tradition, and literary or philosophical culture (Atkins and Finlayson, 2010). Today the speeches emphasise personal experience, be it that of the leader or of an 'ordinary' citizen with whom they have been in communication. Aristotle's recommendation that witnesses be either ancient or 'notable' has been rejected and replaced by the use of witnesses whose authority comes from the fact that they are "lay" people, their "everyday" knowledge and experience substituting for expert testimony. This is a change in "rhetorical culture", in expectations of what counts as valid evidence, of how claims may be justified and of what is deemed to be an appropriate or exemplary "authority".

In reflecting on the context of this development, it is noticeable that it is broadly congruent not only with developments in political communication, but also with the style of popular media in general (see Corner and Pels, 2003). It is certainly evidence of the 'tabloidisation' of political communication, and of the incorporation into speechwriting of a 'journalistic tradition which has always tried to emphasize the importance of introducing stories through personal histories, real-life dramas or humour' (Barnett, 1998: 78). An obvious explanation for this is, simply, the inclusion of tabloid journalists in the speechwriting process. But it has much broader sources 
than that. As Blumler and Kavanagh noted, in a review of developments in political communication in 1999 (when anecdotes were just beginning to become so common): 'The voiced opinions of men and women in the street are being tapped more often in a veritable explosion of populist formats and approaches', including talk-shows, phoneins, invitations to text or email programmes, 'town meetings of the air' and so forth. As audiences 'are exposed to more examples of ordinary people expressing their views and concerns', they wrote, so they 'may expect authority figures to show that they take such concerns seriously' (1999, p. 221).

Similarly, media analysts Livingstone and Lunt identified the way in which television audience discussion programmes (such as Kilroy and The Oprah Winfrey Show) began, in the 1980s and 1990s, to reflect and contribute to a 'broader public anxiety and ambivalence about expertise, education, science and intellectuals in society' (1994, pp. 92, 98; also Ross, 1989; Cummings, 2004). In such programmes, audience members engaged in debate on an equal footing with experts who, finding themselves in 'informal' settings and required to speak in 'ordinary language', were unable to establish their authority in traditional ways (Livingstone and Lunt 1994, pp. 97-98). Thus, claim Livingstone and Lunt, such programmes challenged traditional conceptions of the expert as the possessor of both status and knowledge, implying instead that 'while the expert still has status, the laity [has] knowledge' (1994, p. 128).

The development of the anecdotes, then, is not simply an outcome of techniques and technologies of political campaigning. Although these no doubt contributed to its development, the rise in the use of "proofs" that make reference to the ordinary and everyday is congruent with larger and deeper trends across domains. For instance, 
interestingly, the revalorisation of everyday knowledge is also congruent with fashions in the theory and practice of management and organisation studies, which have become increasingly significant influences upon British government's "new public management". This literature often distinguishes formal knowledge from "tacit" knowledge, thought to be passed on through story and anecdote (see Werr and Stjernberg, 2003). In narrative, it is argued, collective norms may be transmitted, maintained and changed, making it an important tool for leaders of all kinds (out of a vast literature see Denning, 2000; 2007; Brown et.al. 2004). Storytelling - a noted and seemingly successful rhetorical technique of management gurus (Greatbatch and Clark 2005, Ch. 6) - has been viewed as a way of understanding organisations (e.g. Boje, 1991) a development related to the general rise of the concept of "narrative" in both marketing and in politics (Bennett and Edelman, 1985; Oborne, 2005; Salmon, 2010). ${ }^{3}$

The weakness of "expert" in contrast to "everyday" authority seems to be accepted by the speeches we have examined. Here, the privileging of ordinary experience produces a very particular conception of the appropriate criteria for the assessment and validation of political propositions: their congruence with the common sense of the people. Recent historical research by Whipple (2010a; 2010b) suggests that such an appeal to the ordinary may have its roots in a post-war politics of reaction, which was manifested in popular form by grassroots organisations such as the British Housewives League (which campaigned against fluoridation) and the National Viewers and Listeners Association led by Mary Whitehouse. Both emphasised the authenticity of their "ordinary" outlook, which was defined by contrast to an elite imagined to be in charge of the state and public institutions. As Hall has shown, such 
populism was later exemplified by Enoch Powell, whose infamous "rivers of blood" speech centred on the anecdotal citation of a constituent's letter expressing concern about immigration. That speech began with the recounting of a conversation between Powell and 'a constituent, a middle-aged, quite ordinary working man employed in one of our nationalised industries' (1968).

Prior to the 1960s, "the masses" or "the people" appear in conference speeches surprisingly rarely, and usually only as an indistinct and passive third party. In Blackpool in 1966, Edward Heath commended his party for working on 'the real problems of ordinary men and women' with whom he aligned the Conservatives: 'we know and share their fears and anxieties because many of them are the fears and anxieties of us in this hall today ... our fellow citizens'. But it was Thatcher who made such ordinariness central to her Conservatism and her leadership image (Scammell, 1996). For instance, in 1975 she criticised the abolition of grammar schools for hindering the progress of children from 'ordinary' families such as hers had been. Similarly, in 1976, while Labour's leader opposed the 'ordinary worker' to 'the small bands of disrupters in industry' (Callaghan 1976), Thatcher made the distinction much more general, contrasting all ordinary workers to all union activists in her claim that 'those who share our common-sense views are not a small, beleaguered minority. We are a party of ordinary people with ordinary hopes and beliefs, but with extraordinary qualities of tenacity and purpose'. Hers, she said, was 'the truly national Party' and 'On matters that concern ordinary men and women, it is we who represent the majority view, and the Socialists the minority' (Thatcher, 1976; see also 1977,1978$)$. 
The Conservative alignment with "ordinary people" evidently bewildered Callaghan after his electoral defeat in 1979 . He told his party conference:

There was a poll taken during the General Election that, I must say, I found profoundly disturbing ... it said that the Tory Party was regarded as having more concern for ordinary people than the Labour Party. Well, we know what we think about that, but it is not what we think about ourselves, it is what other people perceive about us. That is the problem.

As we noted earlier, 1979 was the year Thatcher, in her conference address, gave the 'ordinary' person a walk-on part as both exemplar and witness: 'The future of this country depends largely on the success of small businesses', she explained, continuing: 'I would like to read to you a letter which I have received from a small businessman in the West Midlands. He put it so much better than I could'. She quoted him at length, explaining how he was 'disillusioned' with 'the Socialist regime and its policies' which had 'forced' him to sell his company. But with the Conservatives back in charge, there had been a 'change of emphasis' and he had formed a new company. 'Please stick to your policy', he wrote, 'It is the only way that we shall eventually solve our problems. It may be hard to bear in the short term, but I truly believe that the bulk of public opinion is now behind a return to the basic commonsense fact that the country as a whole cannot continue to be paid more and more money for less and less work' (1979).

Throughout the 1980s and 1990s, the explicit articulation of the congruity of party ideology and policy with the interests and the common sense of something called “ordinary people" became an ever more extensive feature of conference speeches (e.g. Ashdown, 1992, 1993; Blair, 1996; Brown, 2009; Clegg, 2008; Kinnock, 1987; 
Thatcher, 1980a, 1988, 1990; Smith, 1992, 1993). The anecdotes are an expression of this: in them, "real" and "ordinary" people receive star-billing.

The rise of anecdotes to prominence in British political rhetoric emerges at the intersection of a number of diverse histories: political campaigning; the techniques, technologies and styles of political communication; political marketing; genres of popular media; discourses of knowledge management. It is also part of a longer-term "decline in deference". Most importantly, anecdotes are indicative of a form of democratic populism for which "the people" has a special authority to validate and legitimate claims about the world and what is to be done about it. But they are not only a manifestation of these developments; they are also a response to it.

As Michael Saward has convincingly argued, there are two dimensions to 'representation': a formal relationship in which one is authorised to act on behalf of another, and a symbolic or aesthetic relationship in which one thing stands for or embodies another: 'political figures (or political parties or other groups, for example) make representations of their constituencies, their countries, themselves ... these representations are an unavoidable part of a "substantive acting for" (2006, p. 301). Laclau similarly recognizes that representation is 'a two-way process: a movement from represented to representative, and a correlative one from representative to represented' (2007, p. 158). The legitimacy of representation is thus aesthetic as well as legal-rational, and rests in part on the adequacy and persuasiveness of symbolic forms. That persuasiveness has a history. Those whom people trust, the types of authority they accept, is a part of political contestation and also the outcome of a kind of negotiation between represented and representative. The "popular voice" and 
"everyday knowledge" have attained prominence in contemporary public culture in a way that is congruent with a particular sort of democratic populism for which "the people" possess intrinsic qualities, knowledge and insights. This has created an "imperative of argument", requiring leaders to prove themselves in and through the terms of the ordinary. The anecdote is a simple device for doing so. It helps one to balance the line between exemplar and example, presenting an image of the public to the public in ways that may engender identification. It enables the incorporation of the authority of the "ordinary" without reducing the speaker to it. In the anecdote the words and experiences of the public become part of what the politician has to say (yet it is still the politician who says it and they may be identified with it). It is an easy tool for use in adapting to a populist rhetorical culture.

\section{Conclusion}

When Cameron, in the general election leaders' debate, related his encounter with Neal Forde, he was employing a rhetorical strategy of wide use but, in British politics, relatively recent prominence. He was seeking to justify a number of linked claims about immigration by using Forde as a kind of "authority", and as an exemplary immigrant; attempting to shape his own ethos in the eyes of the public while showing that he understood and listened to the "ordinary" person; seeking to gain authority from his association with an "ordinary person" and to prove that he could represent the people of the nation because he knew them and shared their feelings. He was also responding to - and perpetuating - a broader "rhetorical culture" in which personal and everyday experience is evidence of the same weight, if not more, as anything that can be provided by experts or that abstracts from the particular to the general. 
Rhetorical Political Analysis - because it attends to the multiple forms of proof at work in political speech - can help make visible the broader context of political claim and counter-claim. It can help us to identify the "rhetorical culture" of assumptions and expectations about who and what has authority, and about how people should be addressed if they are to identify with a speaker and perhaps be persuaded. Research into the historical and cultural conditions of the production and circulation of ideas and arguments in politics should include study of such rhetorical cultures, which can help us to connect research into political communication, marketing and campaigning with research into the rise and fall of "ideational" and ideological forces in politics.

In this article we have examined just one rhetorical technique - the anecdote - and sought to understand how it works and what might be the implications and meaning of its recent rise to prominence. That rise indicates a change in what counts as an authority, a development in what is a good "exemplar", and thus a much broader ideological development that is related to changes in the techniques and technologies of political communication, in the styles and modes of political reporting, and in the "epistemological culture" found in, for instance, popular television and the discourse of personnel management. The anecdote also reproduces, validates and perpetuates that change.

Locke, in the Essay Concerning Human Understanding, was critical of arguments that relied on respect for what an authority has said. He thought it a kind of unjust use of force. 'When men are established in any kind of dignity,' he wrote, 'it is thought a breach of modesty for others to derogate any way from it, and question the authority of men, who are in possession of it'. When Locke wrote these words that perception of 
immodesty or 'insolence' came from the fact that a person was placing his opinion 'against the current stream of antiquity' (1838, p. 524). Our study of anecdotes suggests that this is no longer a problem. Today it is thought unwise to risk the appearance of going against the stream of "ordinary" opinion and as a consequence it is imperative for political leaders to incorporate the ordinary into their appearances.

\section{References}

Aristotle (2004) The Art of Rhetoric. London: Penguin Books Ltd.

Ashdown, P. (1992) Speech to the Liberal Democrat Party Conference, 17 September.

(1993) Speech to the Liberal Democrat Party Conference, 23 September. (1996) Speech to the Liberal Democrat Party Conference, 24 September.

Atkins, J. and Finlayson, A. (2010) “"As Shakespeare so Memorably Said...”: The

Rhetoric of Quotation in British Political Speech'. Paper presented at the $60^{\text {th }}$ Annual Conference of the Political Studies Association, 31 March.

Bale, T. (2010) The Conservative Party: From Thatcher to Cameron. Cambridge: Polity Press.

Barnett, S. (1998) 'Dumbing Down or Reaching Out: Is it Tabloidisation wot done it?’ Political Quarterly, 69 (B), 79-90.

Beard, A. (1999) The Language of Politics. London: Routledge.

Bennett, W. L. and Edelman, M. (1985) 'Toward a New Political Narrative', Journal of Communication, 35 (4), 156-171.

Benson, T.W. (ed.) (1993), Landmark Essays on Rhetorical Criticism. London: Routledge. 
Bentham, J. (1952) The Handbook of Political Fallacies. New York: Harper Torchbooks.

Bevir, M. and Rhodes, R.A.W. (2003) Interpreting British Governance. London: Routledge.

(2007) Governance Stories. London: Routledge. (2008) 'Authors' Response: Politics as Cultural Practice', Political Studies Review, 6 (2), 170-177.

Bitzer, L. (1999) 'The Rhetorical Situation', reprinted in J. Lucaites et al. (eds.) Contemporary Rhetorical Theory. London: Guilford Press, pp. 217-226.

Blair, T. (1996) Speech to the Labour Party Conference, 1 October. (1998) Speech to the Labour Party Conference, 29 September. (2000) Speech to the Labour Party Conference, 26 September. (2002) Speech to the Labour Party Conference, 1 October. (2003) Speech to the Labour Party Conference, 30 September. (2004) Speech to the Labour Party Conference, 28 September. (2006) Speech to the Labour Party Conference, 26 September.

Blumler, J.G. and Kavanagh, D. (1999) 'The third age of political communication: Influences and features', Political Communication, 16 (3), 209-230.

Boje, D.M. (1991) 'Consulting and Change in the Storytelling Organisation', Journal of Organizational Change Management, 4 (3), 7-17.

Brown, G. (2007) Speech to the Labour Party Conference, 24 September. (2008) Speech to the Labour Party Conference, 23 September. (2009) Speech to the Labour Party Conference, 29 September. 
Brown, J.S., Denning, S., Groh, K. and Prusak, L. (2004) Storytelling in Organizations: Why Storytelling is Transforming 21st Century Organisation and Management. Butterworth: Heinemann.

Burke, K. (1969a) A Grammar of Motives. London: University of California Press, Ltd. (1969b) A Rhetoric of Motives. London: University of California Press,

Ltd.

Burkeman, O. (2010) 'Chapter and Twitterverse: Cameron’s debate anecdotes picked apart on web', Guardian, 16 April.

Callaghan, J. (1976) Speech to the Labour Party Conference, 28 September. (1979) Speech to the Labour Party Conference, 2 October.

Cameron, D. (2006) Speech to the Conservative Party Conference, 4 October. (2007) Speech to the Conservative Party Conference, 3 October. (2008) Speech to the Conservative Party Conference, 1 October. (2009) Speech to the Conservative Party Conference, 8 October. (2010) Speech to the Conservative Party Conference, 6 October.

Campbell, M. (2006) Speech to the Liberal Democrat Party Conference, 21 September. (2007) Speech to the Liberal Democrat Party Conference, 20 September.

Charteris-Black, J. (2005) Politicians and Rhetoric: The Persuasive Power of Metaphor. Basingstoke: Palgrave Macmillan.

Chilton, P. (2003) Analysing Political Discourse: Theory and Practice. London: Routledge

Clegg, N. (2008) Speech to the Liberal Democrat Party Conference, 17 September. (2009) Speech to the Liberal Democrat Party Conference, 23 September. 
(2010) Speech to the Liberal Democrat Party Conference, 20 September.

Coleman, S. and Ross, K. (2010) The Media and the Public: 'Them' and 'Us' in Media Discourse. Oxford: Wiley-Blackwell.

Connolly, W. (1974) The Terms of Political Discourse. Lexington, Mass: Heath.

Corner, J. and Pels, D. (eds.) (2003) Media and the restyling of politics: consumerism, celebrity and cynicism. London: Sage.

Cummings, D. (2004) The Changing Role of the Public Intellectual. London: Routledge.

Denning, S. (2001) The Springboard: How Storytelling Ignites Action in KnowledgeEra Organizations. Woburn, MA: Butterworth-Heinemann. (2007) The Secret Language of Leadership: How Leaders Inspire Action Through Narrative. San Francisco, CA: Jossey-Bass.

Duncan Smith, I. (2001) Speech to the Conservative Party Conference, 10 October.

Edelman, M. J. (1985) The Symbolic Uses of Politics. Urbana: University of Illinois Press.

Edelman, M. J. (1988) Constructing the Political Spectacle. Chicago, IL: University of Chicago Press.

Fairclough, N. (2001) Language and Power. Harlow: Pearson Education Ltd.

Faucher-King, F. (2005) Changing parties: an anthropology of British political party conferences. Basingstoke: Palgrave Macmillan.

Finlayson, A. (2003) Making Sense of New Labour. London: Lawrence and Wishart. (2004) 'Political Science, Political Ideas and Rhetoric', Economy and Society, 33 (4), 528-549.

(2007) 'From Beliefs to Arguments: Interpretive Methodology and

Rhetorical Political Analysis', British Journal of Politics and International Relations, 
$9(4), 545-563$.

(2012) 'Rhetoric and the Political Theory of Ideologies', Political Studies

(forthcoming).

Finlayson, A. and Martin, J. (2008) “'It Ain’t What You Say...”: British Political

Studies and the Analysis of Speech and Rhetoric', British Politics, 3, 445-464.

Fish, S. (1989) Doing What Comes Naturally: Change, Rhetoric and the Practice of Theory in Literary and Legal Studies. Oxford: Clarendon Press.

Freeden, M. (1998) Ideologies and Political Theory: A Conceptual Approach.

Oxford: Clarendon Press.

Gaffney, J. (1991) The Language of Political Leadership in Contemporary Britain.

Basingstoke: Macmillan Academic and Professional Ltd. (2001) 'Imagined Relationships: Political Leadership in Contemporary

Democracies', Parliamentary Affairs, 54 (1), 120-133.

Glynos, J. and Howarth, D. (2007) Logics of Critical Explanation in Social and Political Theory. London: Routledge.

Glynos, J., Howarth, D., Norval, A. and Speed, E. (2009) Discourse Analysis: Varieties and Methods, ESRC National Centre for Research Methods, NCRM/014.

Greatbatch, D. and Clark, T. (2005) Management Speak: Why we Listen to What Management Gurus Tell Us. London, Routledge.

Hague, W. (1999) Speech to the Conservative Party Conference, 7 October. (2000) Speech to the Conservative Party Conference, 5 October.

Hall, S. and Jacques, M. (1989) New Times: The Changing Face of Politics in the 1990's. London: Lawrence and Wishart.

Hampton, T. (1990) Writing from History: The Rhetoric of Exemplarity in Renaissance Literature. New York: Cornell University Press. 
Hay, C. (2007) Why We Hate Politics. Cambridge: Polity Press.

Heath, E. (1966) Speech to the Conservative Party Conference

Hirschmann, A.O. (1991) The Rhetoric of Reaction. Harvard: Belknap Press.

Howard, M. (2004) Speech to the Conservative Party Conference, 5 October. (2005) Speech to the Conservative Party Conference, 6 October.

Kennedy, C. (2000) Speech to the Liberal Democrat Party Conference, 21 September. (2004) Speech to the Liberal Democrat Party Conference, 23 September.

Kenny, C. (2010) 'At ideological loggerheads? Identifying and clarifying the discursive differences between Blair and Brown on education', British Politics, 5, $367-384$.

Kinnock, N. (1987) Speech to Labour Party Conference, 29 September.

Laclau, E. (1990) New Reflections on the Revolution of Our Time. London: Verso.

Laclau, E. (2007) On Populist Reason. London: Verso.

Lanham, R.A. (1991) A Handlist of Rhetorical Terms, second edition. London: University of California Press, Ltd.

Lawrence, J. (1998) Speaking for the People. Party, Language and Popular Politics in England, 1867-1914. Cambridge: Cambridge University Press.

(2006) 'The Transformation of British Public Politics After the First

World War', Past and Present, 190 (1), 185-216.

(2009) Electing Our Masters: The Hustings in British Politics from

Hogarth to Blair. Oxford: Oxford University Press.

Lewis, W.F. (1987) 'Telling America's Story: Narrative Form and the Reagan Presidency', Quarterly Journal of Speech, 73, 280-302.

Livingstone, S. and Lunt, P. (1994) Talk on Television: Audience Participation and Public Debate. London: Routledge. 
Locke, J. (1838) An Essay Concerning Human Understanding. London: T. Tegg and Son.

Major, J. (1995) Speech to the Conservative Party Conference, 13 October. (1996) Speech to the Conservative Party Conference, 11 October.

Matthew, H.C.G. (1987) 'Rhetoric and Politics in Britain, 1860-1950', in P.J. Waller (ed.), Politics and Social Change in Modern Britain. Brighton: Harvester Press, pp. $34-58$.

Meisel, J. (2001) Public Speech and the Culture of Public Life in the Age of Gladstone. New York: Columbia University Press.

Miliband, E. (2010) Speech to the Labour Party Conference, 28 September.

Nelson, J.S., Megill, A. and McCloskey, D.N. (eds.) (1987) Rhetoric of the Human Sciences: Language and Argument in Scholarship and Public Affairs. Madison, WI: The University of Wisconsin Press.

Oborne, P. (2005) The Rise of Political Lying. London: The Free Press.

Perelman, C. and Olbrechts-Tyteca, L. (1969) The New Rhetoric: A Treatise on Argumentation, trans. J. Wilkinson and P. Weaver. Notre Dame IN: University of Notre Dame Press.

Powell, E. (1968) Speech to a meeting of the Conservative Association, 20 April.

Ross, A. (1989) No respect: Intellectuals and popular culture. New York: Routledge. Rowland, R.C. (1999) Analyzing Rhetoric: A Handbook for the Informed Citizen in a New Millennium. Dubuque, IA: Kendall Hunt Publishing Company.

Salmon, C. (2010) Storytelling: Bewitching the Modern Mind. London: Verso.

Savigny, H. (2005) 'Ontology and Epistemology in Political Marketing: Keeping it Real', Journal of Political Marketing, 6 (2/3), 33-53.

Saward, M. (2006) 'The Representative Claim', Contemporary Political Theory, 5, 
$297-318$.

Scammell, M. (1996) 'The Odd Couple: Marketing and Maggie', European Journal of Marketing, 10/11, 130.

(2007) 'Political Brands and Consumer Citizens: The Rebranding of Tony

Blair', The Annals of the American Academy of Political and Social Science, 611 (1),

176-192.

Serjeantson, R.W. (2007) 'Testimony: the artless proof', in S. Adamson, G.

Alexander and K. Ettenhuber (eds.) Renaissance Figures of Speech. Cambridge:

Cambridge University Press, pp. 179-194.

Smith, J. (1992) Speech to the Labour Party Conference, 29 September.

(1993) Speech to the Labour Party Conference, 28 September.

Smith, G. and Hirst, A. (2001) 'Strategic Political Segmentation: A New Approach

for a New Era of Political Marketing', European Journal of Marketing, 35, (9/10),

1058-1073.

Steel, D. (1979) Speech to the Liberal Assembly

Thatcher, M. (1975) Speech to the Conservative Party Conference, 10 October. (1976) Speech to the Conservative Party Conference, 8 October. (1977) Speech to the Conservative Party Conference, 14 October. (1978) Speech to the Conservative Party Conference, 13 October. (1979) Speech to the Conservative Party Conference, 12 October. (1980a) Speech to the Conservative Party Conference, 10 October. (1980b) Speech to Finchley Chamber of Commerce, 20 June. (1988) Speech to the Conservative Party Conference, 14 October. (1989a) Speech on receiving the freedom of the City of London, 26 May. (1989b) Speech at Lord Mayor's Banquet, 13 November. 
(1990) Speech to the Conservative Party Conference, 12 October.

Toye, R. (2011) 'The Rhetorical Premiership: A New Perspective on Prime

Ministerial Power Since 1945', Parliamentary History, 30 (2), 175-192.

Werr, A. and Stjernberg, T. (2003) 'Exploring Management Consulting Firms as

Knowledge Systems', Organization Studies, 24 (6), 881-908.

Whipple, A. (2010a) 'Into Every Home, Into Every Body': Organicism and Anti-

Statism in the British Anti-Fluoridation Movement, 1952-1960', Twentieth Century

British History, 21 (3), 330-349.

(2010b) 'Speaking for Whom? The 1971 Festival of Light and the Search

for the "Silent Majority"', Contemporary British History, 24 (3), 319-339.

Wring, D. (2005) The Politics of Marketing the Labour Party. Basingstoke: Palgrave

Macmillan.

The research for this paper formed part of the project 'How the Leader Speaks: British Political Rhetoric and Argumentation', supported by the Leverhulme Trust (grant no. F/00 3910 - How the Leader Speaks) and to whom we are extremely grateful. We also wish to thank the three anonymous referees for their invaluable comments on an earlier draft of this paper.

${ }^{1}$ The debate may be viewed, in its entirety, online: http://www.youtube.com/watch?v=rk5HvJmy_yg

${ }^{2}$ On 20 June 1980 she told the Finchley Chamber of Commerce that she had been 'born and bred in trade' (Thatcher, 1980b); on 26 May 1989 she referred to herself as a grocer 'an honour I share with William Pitt the Younger' (Thatcher, 1989a). Later that year, at the Lord Mayor's Banquet she referred to the fact that she and the mayor 'share the privilege of being grocers, I by birth and you, so to speak, by profession' (Thatcher, 1989b).

${ }^{3}$ Stories were a noted rhetorical technique of President Ronald Reagan; there may be here an element of 'rhetorical policy transfer' (Lewis, 1987). 